\title{
West Jakarta Government's Paradiplomacy towards Global Public in Kalideres Refugee Issues
}

\author{
Ignatius Hubert * (D) and Windy Dermawan (1D) \\ Department of International Relations, Faculty of Social and Political Sciences, \\ Universitas Padjadjaran, 45363, West Java Province, Indonesia \\ * Corresponding Author: ignatius17004@mail.unpad.ac.id
}

\section{ARTICLE INFO}

Publication Info:

Literature Review

How to cite:

Hubert, I., \& Dermawan, $W$.

(2020). West Jakarta

Government's Paradiplomacy

towards Global Public in Kalideres

Refugee Issues. Society, 8(2), 567-

580.

DOI: $10.33019 /$ society.v8i2.218

Copyright $\odot$ () 2020. Owned by Author(s), published by Society

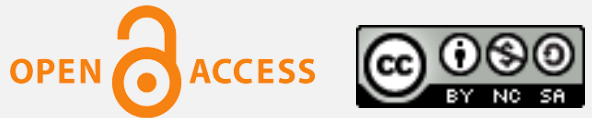

This is an open-access article.

License: Attribution-

NonCommercial-ShareAlike

(CC BY-NC-SA)

Received: August 17, 2020;

Accepted: September 24, 2020;

Published: December 28, 2020;

\section{ABSTRACT}

This research analyzes international refugees' presence in Indonesia, which gives local challenges for the Indonesian subnational Government as a transit location. This research uses a paradiplomacy perspective to analyze the West Jakarta Government's response to the foreign refugees in its territory. West Jakarta is one of the Administrative Cities in the Special Capital Region of Jakarta. This research uses a qualitative research method. The research data sources were collected and analyzed from literature studies, current news, and sociopolitical theories. This research found that West Jakarta Government's paradiplomacy occurs due to differences in regulations applies. Moreover, this process can be parallel alongside the Central Government (Indonesian Government) in handling refugees in their territory following a localregional wisdom approach. The West Jakarta Government's paradiplomacy carried out by coordinating the distribution of aid to refugees, working with stakeholders in handling international and national refugee issues, and managing refugee handling policies in transit locations where refugees live, especially in Kalideres, West Jakarta, Indonesia. These handling efforts aim to prevent horizontal conflicts between refugees and local people and achieve subnational interests in the form of support materially, financially, and politically.
Keywords: Foreign Relations; Paradiplomacy; Refugee; Regional Government; Subnational Interests; Transit Location

Copyright (C) 2020. Owned by Author(s), published by Society. This is an open-access article under the CC-BY-NC-SA license. 


\section{Introduction}

The number of refugees currently reaches around an estimated 26 million people due to conflicts or conditions that endanger their lives worldwide. Two-thirds came from countries currently experiencing prolonged conflicts, such as Syria, South Sudan, Afghanistan, Somalia, and Myanmar (United Nations High Commissioner for Refugees, 2020a). Until now, the issue of human movement across national borders has been going on throughout history. Indonesia has become a transit location for refugees, with around 13,657 refugees in its territory in 2019 (United Nations High Commissioner for Refugees, 2020b). One of these refugee transit locations has become a public concern, namely, in Kalideres, West Jakarta. Around an estimated 400-500 foreign refugees were temporarily housed in small dome tents squashed into every room and spilling out into the concrete car park at the ex-Military District Command building (The Guardian, 2019). The refugees move to Indonesia through legal or illegal channels to reach their final destination country, Australia or New Zealand. Geographically, Indonesia's location is strategic as a transit country. However, due to certain conditions, such as the Australian and New Zealand Government's refugee restriction policy, they were eventually forced to stay for an indefinite period in Indonesian territory (Palmer \& Missbach, 2019).

The existence of refugees in the West Jakarta area has caused problems. The refugees in Kalideres had received attention in the national and international news because their presence allegedly created unrest for local people (CNN Indonesia, 2019b). On the other hand, the refugees felt that their fundamental rights were still not fulfilled by the Indonesian Government and United Nations High Commissioner for Refugees (UNHCR). So they held a demonstration at the UNHCR Representation Office in Indonesia to demand the fulfillment of their rights and accelerate to moving them to the destination country (Bayani \& Gondo, 2019). This conflictual condition has created horizontal problems between residents in the West Jakarta area and refugees (Beritasatu.com, 2019a). This problem is a challenge for the West Jakarta Government to manage the refugee problem in its area. Moreover, this issue has received global attention (Curby, 2019).

Regarding refugees' presence, Indonesia already has Presidential Regulation Number 125 of 2016 concerning Handling of Refugees from Abroad as a form of the Indonesian Government's reference to deal with refugee problems in its region (Missbach et al., 2018). This regulation serves to provide legal rules for refugees in Indonesian territory, regulate the flow of coordination between government agencies responsible for handling refugees, and give Regional Governments greater authority in handling refugee issues in Indonesian territory (Sadjad \& Walden, 2019). In this context, there is already a national governance framework for refugee issues.

Through this regulation, the subnational Government's role (the Regional Government where there are refugee settlements) is to handle refugee problems in coordination with the Central Government. In this case, Indonesia continues to emphasize its role only as a transit country without intending to accommodate refugees permanently. Thus, foreign refugees in Indonesian territory and their interactions with the Indonesian people, International Organizations, and especially the West Jakarta Government, identified them as foreign parties from abroad that must follow applicable legal provisions in Indonesia. Whether the role of subnational actors is classified as paradiplomacy action depends on interpreting the Regional Government actors' interests in their roles and objectives.

In the context of paradiplomacy regulations, Law Number 37 of 1999 concerning Foreign Relations becomes the legal basis for Regional Government in Indonesia's foreign relations activities (Republik Indonesia, 1999). According to Law Number 24 of 2000 concerning

Copyright (C 2020. Owned by Author(s), published by Society. This is an open-access article under the CC-BY-NC-SA license. 
International Treaties, Regional Governments can establish cooperation with other international parties (Republik Indonesia, 2000). Besides, Law Number 23 of 2014 concerning Regional Government also gives Regional Governments the authority to establish foreign relations and cooperation related to regional interests, but still in line with Indonesia's national interests (Republik Indonesia, 2014). Furthermore, this law is followed up by Government Regulation Number 28 of 2018 concerning Regional Cooperation (Republik Indonesia, 2018). Based on this, the West Jakarta Government can operationalize paradiplomacy in implementing foreign relations issues for its subnational interests, including refugees' issue.

\section{Literature Review}

Several previous studies were relevant to refugee governance and paradiplomacy then examined to mark this study's novelty. Andrews (2016); Bulgin (2017); Fincher et al., (2014); Balbo \& Marconi (2006); Zhang et al., (2006) examined the phenomenon of refugees arriving and how the subnational Government's policy response to its. Another study showed how foreign relations of regional manage human movement phenomena across borders (McConnell et al., 2012; Totoricagüena, 2005). There are also several previous studies on the movement of people across national borders (especially transit refugees) related to multi-level governance and national-subnational government relations (Mascareñas \& Amador, 2019; Adamson \& Tsourapas, 2018; Makarychev, 2018; Panizzon \& van Riemsdijk, 2018; Totoricagüena, 2005). Several other studies have also raised the paradiplomacy faced by the issue of human movement across borders in the context of identity issues, particularly regarding the sentiment of self and others (Becker \& Ferrara, 2019; Dreher et al., 2019; Adamson \& Tsourapas, 2018; Gamso \& Yuldashev, 2018; Makarychev, 2018; Vigneswaran, 2008; Balbo \& Marconi, 2006; Totoricagüena, 2005).

These previous studies found that the discussion about the correlation of human movement across national borders, identity issues, and paradiplomacy is a topic that is quite discussed in academia across fields and shows the urgency and research richness of this topic as a contemporary world study problem. This current research mainly focuses on examine West Jakarta Government's paradiplomacy practices in responding to international refugees in its territory and dealing with the refugee problem. This study complements previous studies, especially in terms of the analysis level that takes the West Jakarta Government as a subnational actor and its subnational interests. In addition to the dynamics of national-subnational policies in dealing with refugee issues and the societal impact they cause. This research considering the dynamics of refugees who are not citizens of the country where they come from but often fail to fulfill their human rights by the Regional Government in their interactions with local people and the Regional Government.

West Jakarta Government's paradiplomacy in handling refugees is essential and urgent to study. Especially in referring to the uniformity, synchronization, and simultaneous nature of national policies and interests with subnational policies and interests that can cause deviation or show a separate formality in handling refugees in transit countries. In this condition, West Jakarta only has a position as a transit area for refugees on their way to the destination country, not as the destination country itself.

State actors are no longer the only actors who monopolize foreign relations (Lecours, 2008). Even actors whose roles have been considered minor compared to the state are currently active in carrying out transnational relations. Transgovermental relationships illustrate the increasingly sensitive condition of the formulation of national government policies of one country towards other countries, due to the increasing presence of non-government actors in

Copyright ( ) 2020. Owned by Author(s), published by Society. This is an open-access article under the CC-BY-NC-SA license. https://doi.org/10.33019/society.v8i2.218 
foreign relations (Keohane \& Nye, 1974). Transgovernmentalism interprets as the internationalization of the policy formulation process through interactions between government agencies. Transgovernmentalism, in this research, describes the relationship between the West Jakarta Government and the global public, both state and non-state. Transgovernmentalism is relevant to be studied refers to the relations or diplomacy or foreign relations of the West Jakarta Government as a subnational actor.

Slaughter (1997; 2003) explains how transgovernmental networks undergo a regular and purposeful relationship pattern between various government agencies working across the dividing line between domestic and international spheres. Slaughter explained how NGOs or IGOs with the characteristics and values of governance between international actors within their institutional sphere also play a role in forming a transgovernmental network with various other actors in contemporary international relations. So it can be understood the breadth of studies from the transgovernmental concept itself, including covering the relationships of various transnational actors. The widespread NGO/IGO actors' politicization performance and interaction with various transnational actors are due to support from information and communication technology developments (Willetts, 2001). The main focus of the discussion is the transgovernmental relationship established by the subnational actor (West Jakarta Government) with the transnational IGO actor (UNHCR), in cooperation that benefits both parties who share the same interest in a specific international issue (refugees).

This research also uses the concept of paradiplomacy. This concept explains the theoretical continuation of transgovernmentalism growth in the international community, namely the increasing number of sub-state actors in foreign relations. This concept explains that various actors can carry out state actors' diplomacy in different layers (Criekemans, 2008 as cited in Mukti et al., 2019). According to Chatterji \& Saha (2017), paradiplomacy is a process of constituent units of the state conducting its diplomatic relations to pursue their interests, which may differ from or side by side with their country of origin. Wolff (2007) explains that paradiplomacy is the foreign policy capacity of subnational entities in the form of participation and independence of their diplomacy methods from their home countries in the international arena to pursue specific interests. Meanwhile, in this research, paradiplomacy actor is the West Jakarta Government dealing with the refugee problem. Paradiplomacy also exists at the social and human rights level (Lecours, 2008; Paquin \& LaChapelle, 2005).

The next concept is about refugees. In international relations, refugees' presence is a commonplace that has occurred throughout time, along with various historical events. This research examines refugees' presence from two theoretical perspectives; the human movement across national borders and refugees' identity.

Human movement across national borders shows humans' physical movement from one place to another across territorial boundaries and specific periods for transit or stay (Stalker, 2008). The human movement across national borders in this research is focused on the multilevel management of refugees by the national Government and the West Jakarta subnational government. Often these refugees come to an area with a burden of conflict, identity, culture, and their respective personalities that can be different from the people in their destination countries.

The importance of the second study regarding refugees' identity is in seeing the phenomenon of refugees' presence in Indonesian territory, especially Kalideres. Refugees in the context of identity show the flexibility of identity in society, allowing changes in identity, both cooperative and destructive, between refugees and the local community (Goff \& Dunn, 2004). The identity is one of the concerns in studying the refugee phenomenon to understand the

Copyright ( ) 2020. Owned by Author(s), published by Society. This is an open-access article under the CC-BY-NC-SA license. https://doi.org/10.33019/society.v8i2.218 
construction of refugee identity and its impact on West Jakarta's horizontal conflict. So what becomes an essential question in looking at this situation is how the forms of handling refugees by the West Jakarta Government become a form of paradiplomacy that they do to the global public based on humanity. Especially in the scope of actions or efforts of subnational actors (West Jakarta Government) to assist state actors in the refugee handling process, which ultimately serves West Jakarta's interests, avoiding horizontal conflicts due to the presence of refugees in their area.

\section{Research Methodology}

This research uses qualitative research methods and secondary data based on literature sources, current news, and socio-political theories. The qualitative method used is interpretive. Namely, it interprets visible social phenomena to be analyzed based on the theory or concept used. The qualitative method uses as a reference in data collection, data analysis, and a series of research stages to chronologically understand various social phenomena to create a holistic and complex picture of these phenomena into accountable detailed reports (Creswell \& Poth, 2017). The phenomenon in question is the paradiplomacy carried out by the West Jakarta Government as a subnational actor towards the global public in dealing with refugee problems in its region. Based on the various information obtained, the existing problems were studied and analyzed before giving qualitative conclusions.

\section{Results and Discussion}

There are two main points of view in this research regarding paradiplomacy. The first is the actions and subnational actors' efforts in helping Central Government actors achieve their interests, as a broader effort to fulfill their subnational interests. Second, the subnational actors' interests, namely to deal with the refugee problem, which is increasing in urgency in their respective areas. Paradiplomacy, in the context of this research, is seen in two ways. On the one hand, paradiplomacy is directed at the Central Government so that Regional Governments get legitimacy and even support their actions to deal with refugees' presence in their territory (inside).

On the other hand, subnational governments can optimize their resources in solving these refugees' internal problems in their areas (outside). These two forms of paradiplomacy will be the main focus of this research. In the next section, this research describes various concepts used and their relevance. After that, this research describes the forms of paradiplomacy carried out by the West Jakarta Government in handling refugees' problems in this area as a transit location (Kalideres). The discussion consists of relations with stakeholders in handling international and national refugee problems, distributing aid to refugees, and managing refugees' policies in transit locations.

\subsection{Relations with National and International Organizations}

In general, several organizations play a role in handling refugees in the world, including in Indonesia. For example, the International Organization for Migration (IOM) role as an UNaffiliated non-governmental international organization provides services and advice on immigration to governments and migrants (Bradley, 2017). However, in refugees in Indonesian territory, no other international organization has a significant role as UNHCR to send aid and administer refugee handling. UNHCR plays a role in collecting and distributing aid funds from similar social organizations in Indonesia to be distributed to refugees, such as; Tzu Chi, Dompet Dhuafa, Indonesian Red Cross, and IOM Indonesia (Kompas.com, 2019a). 
The role of UNHCR is essential when looking at the influence of the organization in the context of fulfilling the socio-economic rights of refugees transnationally, where UNHCR is an international organization that is assigned to carry out the mandate of handling refugees in almost all countries in the world. In the Kalideres refugee context, no wonder hundreds of refugees often make protests in front of the UNHCR office in Kebon Sirih, Central Jakarta. They demand fulfilling of their human rights, both in assistance with daily needs, residence status, or other socio-economic needs (Ismuntoro, 2020).

The mandate and task of UNHCR in Indonesia, or other countries around the world, for that matter, is to ensure that every refugee has the right to seek asylum and seek safe protection in another country, with the options integration or repatriation (United Nations High Commissioner for Refugees, n.d.). Meanwhile, to realize their mandate, UNHCR also assists refugees in clean water, sanitation and health care, shelter, blankets, household goods, and food. Furthermore, UNHCR also provides transportation and assistance packages for refugees who choose to return to their countries of origin and develop income-generating projects for refugees who choose to remain (United Nations High Commissioner for Refugees, n.d.). Thus, UNHCR, as an international organization with an intergovernmental governance mandate, as described in the concept of transgovernmentalism, has an independent interest in handling refugees. Namely, humanitarian aid's smooth distribution for refugees' welfare in transit countries and ensuring permanent solutions for the international refugee crisis, including locally in specific domestic locations. These two aspects of UNHCR's interests as a transnational actor will be aspects of relational studies in UNHCR's relationship with the West Jakarta Government.

In distributing aid as described in the previous section, UNHCR cannot stand alone to make it happen because it can violate regulations or laws in the country where UNHCR operates. Furthermore, UNHCR also has limitations in terms of funds, resources, and operational capabilities to ensure optimal aid distribution to refugees in a country and region. So it is not uncommon, UNHCR also collaborates with various stakeholders in a country to achieve their goals. In Indonesia, UNHCR is involved in forging sustainable cooperation in handling refugees with various Regional Governments. In this context, regulations regarding cooperation between regions and foreign parties as previously described are relevant, coupled with the principle of international organizations' operation in the Indonesian territorial.

Regarding refugees in the Kalideres area, of course, the context and presence of the Regional Government's role are essential in the handling process. Based on the perspective of UNHCR, this has several advantages, among others, to understand the regional context in preparing refugee management planning and the provision of various handling resources (funds, human resources, time, and others). In these relations, Regional Governments also need UNHCR expertise in refugee management to help Regional Governments deal with refugees' presence and dynamics in their territory. These are the things that underlie the relationship between UNHCR and the Regional Governments of a country. Concretely, the cooperation built between UNHCR and the Regional Government from the beginning of moving refugees to the Kalideres ex-Military District Command building transit location. This collaboration also in the process of finding a more humane location for the displacement of refugees as another option for placing refugees in the Kalideres ex-Military District Command building (VIVA.co.id, 2019). Another form of cooperation is voluntary repatriation for refugees from countries that are relatively safe from threats and deportation for refugees whose asylum status has been rejected by UNHCR (Beritasatu.com, 2019b). On the other hand, the Jakarta government also proposed a form of disapproval due to the ineffective discourse of relocating refugees from the Kalideres

Copyright (C) 2020. Owned by Author(s), published by Society. This is an open-access article under the CC-BY-NC-SA license. https://doi.org/10.33019/society.v8i2.218 
ex-Military District Command building some time ago. It is considered detrimental to the Special Capital Region of Jakarta's interests in general and West Jakarta in particular (Kompas.com, 2019b).

Of course, the whole process of handling and formulating refugee policies was not carried out specifically with the West Jakarta Government. Generally, this cooperation is carried out with government institutions at higher levels, including the Provincial Government of the Special Capital Region of Jakarta and the Central Government, according to the territorial jurisdiction structure and the authority to deal with foreign actors. However, one similar value from the various collaborations between Indonesia and UNHCR is that refugees' policy coordination and handling must involve Local-Regional Governments. It is very crucial for policy fulfillment and efficient handling. In this case, the West Jakarta Government's paradiplomacy is carried out in collaboration with foreign actors to maximize efforts to handle refugees as best as possible for the common interest.

Especially in terms of policy coordination and handling of refugees must refer to the West Jakarta Government's territorial and its interests. As explained in the previous, a subnational actor's interests in carrying out paradiplomacy can conflict with or in line with the national interest. In this refugee issue, the West Jakarta Government and the Indonesian Government's interests are generally in line. The Indonesian Government wants to resolve the refugee problem and fulfill these refugees' human rights to avoid international criticism. Meanwhile, the West Jakarta Government wants to resolve the horizontal conflict between the refugees and the local community, finding other places for refugee placement, and get more allocation of handling resources if refugee displacement is impossible. Regarding its relationship with UNHCR, several perspectives from the West Jakarta Government's paradiplomacy, consisting of helping them accelerate the handling of refugees in their territory and help channel refugees' handling.

\subsection{Distribution Implementation of Humanitarian Assistance for Refugees}

UNHCR cannot directly assist refugees. So in carrying out this function, UNHCR needs assistance in coordinating aid distribution at the national and regional levels. In this case, with the existence of a partnership as previously described, the West Jakarta Government has a role in channeling this assistance to the refugees. UNHCR and the Special Capital Region of Jakarta Government give the West Jakarta Government the mandate to channel assistance.

The Provincial Government assists refugees in food, hygiene facilities, and a temporary residence location in the Kalideres ex-Military District Command building, which has undergone an extension of their stay permit indefinitely (Kompas.com, 2019a). Meanwhile, with UNHCR, the West Jakarta Government helps distribute various assistance in distributing logistical needs and infrastructure such as portable toilets. Furthermore, the latest data shows that during the COVID-19 pandemic, assistance provides medical devices such as masks and hand sanitizers for refugees who are still living at the Kalideres transit site to date (Tempo.co, 2020). The West Jakarta Government carries out various forms of aid distribution and a constant supply of resources crucial for refugees' lives in the shelter, namely electricity and water in the Kalideres ex-Military District Command building (ANTARA News, 2019).

Based on explanations of several forms of assistance channeled through the West Jakarta Government, it can be understood that subnational actors' crucial role in distributing aid to international refugees. There are several central roles that Regional Governments play in this context, which other actors may not play. The first is the Government's expertise, understanding, and experience at the smallest administrative level to handle domestic problems

Copyright ( $(2020$. Owned by Author(s), published by Society. This is an open-access article under the CC-BY-NC-SA license. https://doi.org/10.33019/society.v8i2.218

573 
in the region. For example, the West Jakarta Government's role in providing relief assistance for refugees in their area. In this case, West Jakarta Government is a government institution that has experienced building interactions and dynamics with the community, refugees, and other stakeholders every day. Therefore, the West Jakarta Government has a higher level of capability and credibility to handle the process of distributing assistance than other organizations or institutions that do not have experience or understanding of West Jakarta's socio-economic context area.

The second is related to the focus of the scope of operations. Because the West Jakarta Government only specifically has the authority to deal with refugees in its territory, it can mobilize the overall focus of handling and distributing aid to resolve these problems. The same cannot apply to other organizations or institutions, such as UNHCR, which must distribute refugee assistance to all transit locations where refugees live in Indonesia. So that the distribution of aid in each location could not fully get the focus of their attention. In this context, UNHCR plays a role only in broad oversight of the rate of the distribution process itself, while Regional Governments are at the forefront of aid distribution for refugees in their respective areas.

From a paradiplomacy perspective, it must consider regional interests in every action of subnational actors. In this case, the West Jakarta Government can use aid distribution to refugees to avoid horizontal conflicts between refugees who demand the fulfillment of their rights and the local community. Of course, the distribution of this assistance is a positive effort by the Regional Government to fulfill the refugees' human rights, even though Indonesia is only a transit country for refugees. Besides, Regional Governments can also build positive relationships with refugees and supervisory aid agencies such as UNHCR. This positive relationship with refugees can help prevent social disruption due to refugee protests directed at UNHCR rather than against the West Jakarta Government. Meanwhile, the positive relationship with UNHCR can be used by the West Jakarta Government in its efforts to obtain more aid allocations for refugees in its area. Further, it can create conditions conducive to the West Jakarta Government's interests in its territory, as previously explained.

\subsection{Management of Policy for Handling Refugees at Transit Site}

Paradiplomacy activities include various subnational actors' activities with actors from abroad. By referring to refugees' status in Indonesia who are not Indonesian citizens and come from outside the country of Indonesia, their presence in Indonesian territory becomes an anomaly. The strategy for handling their condition becomes an issue at the transnational level. Thus, if carried out by subnational government actors, handling and even relations with refugees can be said to be in the realm of paradiplomacy.

In this handling process, of course, the Indonesian state cannot rely solely on the national Government's capacity and capability, which has comprehensive attention to refugees' presence throughout Indonesia. In this case, the handling of refugees locally becomes essential, both for the national interest to maintain the country's stability and local interests to prevent horizontal conflicts based on identity in the Kalideres community. The process of managing this policy also involves non-state foreign actors, namely UNHCR. All of these actors interact to solve refugees' problem in Indonesia so that it does not prolong and cause further problems both locally and nationally.

As for the highest level of policy formulation, coordination of refugee handling policy design occurs between the Ministry of Foreign Affairs, the Coordinating Ministry for Political, Legal and Security Affairs, the Ministry of Social Affairs, Jakarta Provincial Government, and 
UNHCR (Beritasatu.com, 2019c). In this policy coordination team, there is an understanding that handling refugees are under the Jakarta Provincial Government's responsibility. However, of course, the West Jakarta Government can offer its perspective through coordination with Jakarta's Provincial Government, considering the local area occupied by refugees' presence. The West Jakarta Government is an actor who interacts directly with refugees.

By considering these various factors, the policy for handling refugees carried out by the West Jakarta Government is crucial to pay attention to differences in various refugee handling policies at the regional and national levels. Significantly based on the paradiplomacy perspective, the policy of handling refugees by subnational actors can show specific alignments that vary from national interests.

In general, the West Jakarta Government regulates refugee life at the Kalideres ex-Military District Command building, including various aspects of refugees' lives at the transit location. The West Jakarta Government is responsible for refugees' public order at transit locations (CNN Indonesia, 2019a) by considering the potential for identity conflicts between refugees and the local community. Besides, the West Jakarta Government is also required to pay attention to the conditions and various needs of the refugees, including providing for their various daily needs by distributing aid and those that have recently become a concern as well, helping ensure the health of refugees amid the conditions of the COVID-19 pandemic (ANTARA News, 2020). In these various policies and actions, the West Jakarta Government has a fairly intense relationship with refugees in its territory as international parties in need of humanitarian assistance and a potential threat to the local community's public order.

Of course, the various considerations described in the previous are essential, given the different perspectives and interests in responding to refugees' presence in an area. Which consists of 1) the local community wants social justice, public order, and freedom from the perception of threats that refugees' arrival presents to their sphere of life. 2) International institutions that require semi-permanent refugee transit locations in transit countries until a receiving country is found willing to accommodate refugees permanently. 3) Refugees who need assistance to support their daily lives. These different and sometimes conflicting interests are prone to causing conflict in West Jakarta residents. Thus, the West Jakarta Government's role in this perspective is crucial to mediate the region's different interests. As much as possible to avoid broader conflicts between the various stakeholders who interact in their area.

Based on the explanations above, the West Jakarta Government has subnational interests in line with the Indonesian Government. Precisely in terms of handling refugees in their territory in a coordinated, safe, and smooth manner. This interest is also in line with the interests held by UNHCR, as a West Jakarta relational partner in the issue of handling refugees in their territory. Based on the previous explanations, the three actors also have their synergy and collaboration level between one actor and another to achieve this common interest.

Meanwhile, even though they generally have in line interests, these three actors have their preferences, priorities, and methods to make the maximum contribution according to their capabilities and authority in handling West Jakarta refugees' presence. The West Jakarta Government has a higher priority value for funding support, refugee relocation, maintaining refugee order, and others directly related to managing refugees' presence in the field. Besides, as previously explained, it is essential to understand that there was no direct physical violence resulting from the horizontal conflict sentiment between refugees and West Jakarta residents. However, the West Jakarta government's next primary concern in this perspective is related to the potential for conflict due to interactions between the residents and the refugees in the West Jakarta area. So, West Jakarta Government's paradiplomacy so far has been carried out based on

Copyright (C 2020. Owned by Author(s), published by Society. This is an open-access article under the CC-BY-NC-SA license. https://doi.org/10.33019/society.v8i2.218 
the consideration of the achievement of the two perspectives of the interests of the subnational actor (West Jakarta), in its broader relationship with the national actor (Central Government), and transnational actor (UNHCR).

\section{Conclusion}

Due to conflict, or various other factors from one country to another, the human movement is a phenomenon that is increasingly in contemporary international relations. In Indonesia, refugees' presence in Kalideres ex-Military District Command building as a transit location often led to horizontal conflicts between refugees and the local community regarding identity factors. Meanwhile, in handling refugees' dynamics, many stakeholders play a role in it, both from within the country and outside, consisting of the Indonesian Government, UNHCR, and Jakarta Provincial Government, including the West Jakarta Government, as a transit location for refugees.

In dealing with the dynamics of the relationship between refugees and subnational actors (the West Jakarta Government), this research uses paradiplomacy theory. The relationship between various national and international stakeholders and the West Jakarta Government classify into a paradiplomacy theory. The West Jakarta Government's local-regional interests in handling refugees consist of managing refugees' presence in West Jakarta and preventing conflicts between refugees and the local community. In this context, the West Jakarta Government conducts aid distribution relationships, establishes relations with various stakeholders in handling refugee problems, and manages refugees' policies in transit locations. The main objectives are to solve the horizontal problems caused by refugees' presence in their area and get support (material and financial) from various stakeholders if refugees' problem continues unresolved.

This precedence shows the vital role of the subnational paradiplomacy actors in contemporary international relations dynamics. This development is likely to be more evident in today's Indonesia as the capabilities, understanding, and demands of the conditions faced by subnational actors in dealing with problems involving international actors outside their home countries, such as on the issue of refugees, tourism, business, and others. The Indonesian Government could benefit from this development if the Indonesian Government can adequately assimilate the national interest as a broader and integrated part of various subnational actors' local-regional interests in issues specific to their interests. For example, the West Jakarta Government handles refugees' presence in their area and the various solutions they have taken (including paradiplomacy) in the handling process. In handling refugees, it is necessary to ensure an understanding and one vision in various institutions, organizations, and actors across the bureaucracy to implement foreign relations, maximize state interests, and minimize subversive tendency paradiplomacy towards national interests.

\section{Acknowledgment}

The authors are grateful to express gratitude to all of those who have had the pleasure to work during this research conducted.

\section{Declaration of Conflicting Interests}

The authors have declared no potential conflicts of interest concerning the research, authorship, and/or publication of this article. 


\section{References}

Adamson, F. B., \& Tsourapas, G. (2018). Migration Diplomacy in World Politics. International Studies Perspectives, 20(2), 113-128. https://doi.org/10.1093/isp/eky015

Andrews, A. L. (2016). Legacies of Inequity: How Hometown Political Participation and Land Distribution Shape Migrants' Paths into Wage Labor. World Development, 87, 318-332. https://doi.org/10.1016/j.worlddev.2016.07.003

ANTARA News. (2019, October 11). Pemprov DKI beri bantuan listrik dan air untuk pengungsi Kalideres. Retrieved from https:/ /www.antaranews.com/berita/1108630/pemprov-dkiberi-bantuan-listrik-dan-air-untuk-pengungsi-kalideres

ANTARA News. (2020, July 23). 200 pengungsi Kalideres jalani tes usap di Jakarta Barat. Retrieved from https://www.antaranews.com/berita/1629006/200-pengungsikalideres-jalani-tes-usap-di-jakarta-barat

Balbo, M., \& Marconi, G. (2006). International migration, diversity and urban governance in cities of the South. Habitat International, 30(3), 706-715. https://doi.org/10.1016/j.habitatint.2005.04.004

Bayani, M. B., \& Gondo, T. (2019, July 16). Refugees Are Humans Too... and Bring Many Benefits to Local Communities. Retrieved from https://jakartaglobe.id/context/refugees-are-humans-too-and-bring-many-benefits-tolocal-communities

Beritasatu.com. (2019a, July 15). Pencari Suaka Ditolak Masyarakat, Lurah dan Camat Diminta Lakukan Pendekatan. Retrieved from https:/ / www.beritasatu.com/megapolitan/564460/pencari-suaka-ditolak-masyarakatlurah-dan-camat-diminta-lakukan-pendekatan

Beritasatu.com. (2019b, August 6). Ini Langkah Pemerintah Tangani Pengungsi Luar Negeri. Retrieved from https://www.beritasatu.com/nasional/568200/ini-langkah-pemerintahtangani-pengungsi-luar-negeri

Beritasatu.com. (2019c, September 8). Kemlu: Wapres Instruksikan Penanganan Pengungsi Kalideres. Retrieved from https://www.beritasatu.com/dunia/573876/kemlu-wapresinstruksikan-penanganan-pengungsi-kalideres

Becker, S. O., \& Ferrara, A. (2019). Consequences of forced migration: A survey of recent findings. Labour Economics, 59, 1-16. https:/ / doi.org/10.1016/j.labeco.2019.02.007

Bradley, M. (2017). The International Organization for Migration (IOM): Gaining Power in the Forced Migration Regime. Refuge: Canada's Journal on Refugees, 33(1), 97-106. https:/ / doi.org/10.25071/1920-7336.40452

Bulgin, K. (2017). The Refugee Identity Crisis: How Athens is Trying to Bridge the Gap Between a Person and their Homeland through Heritage and Meaning Making. Skepsi, 10, 39-63. Retrieved from https:/ / blogs.kent.ac.uk/skepsi/files/2018/12/full-issue-6.pdf\#page=45 Chatterji, R., \& Saha, S. (2017). Para-diplomacy: Concept and the Context. India Quarterly: A Journal of International Affairs, 73(4), 375-394. https://doi.org/10.1177/0974928417731638

CNN Indonesia. (2019a, August 23). Ricuh Para Pencari Suaka di Kalideres Dipicu Rebutan Makanan. Retrieved from https://www.cnnindonesia.com/nasional/2019082316544620-424138/ricuh-para-pencari-suaka-di-kalideres-dipicu-rebutan-makanan

CNN Indonesia. (2019b, September 20). Pagar Gedung Pengungsian Para Pencari Suaka Disegel. Retrieved from https://www.cnnindonesia.com/nasional/20190920072142-20432154/pagar-gedung-pengungsian-para-pencari-suaka-disegel

Creswell, J. W., \& Poth, C. N. (2017). Qualitative Inquiry E Research Design: Choosing Among Five Approaches. Thousand Oaks: SAGE Publications. 
Curby, N. (2019, September 16). Evicted and arrested: refugees in Indonesia under pressure. Retrieved from https://overland.org.au/2019/09/scenes-from-indonesia-near-theborder-with-australia/comment-page-1/

Dreher, A., Fuchs, A., \& Langlotz, S. (2019). The effects of foreign aid on refugee flows. European Economic Review, 112, 127-147. https:// doi.org/10.1016/j.euroecorev.2018.12.001

Fincher, R., Iveson, K., Leitner, H., \& Preston, V. (2014). Planning in the multicultural city: Celebrating diversity or reinforcing difference? Progress in Planning, 92, 1-55. https:// doi.org/10.1016/j.progress.2013.04.001

Gamso, J., \& Yuldashev, F. (2018). Does rural development aid reduce international migration? World Development, 110, 268-282. https://doi.org/10.1016/j.worlddev.2018.05.035

Goff, P. M., \& Dunn, K. C. (2004). Introduction: In Defense of Identity. In P. M. Goff, \& K. C. Dunn (Eds.), Identity and Global Politics: Empirical and Theoretical Elaborations (pp. 1-8). Houndmills, Basingstoke: Palgrave Macmillan.

Ismuntoro, M. (2020, July 13). Pencari Suaka Tagih Bantuan Kemanusiaan UNHCR di Jakarta. Retrieved from https://indonesiainside.id/serbaserbi/foto/2020/07/14/275831

Keohane, R. O., \& Nye, J. S. (1974). Transgovernmental Relations and International Organizations. World Politics, 27(1), 39-62. https://doi.org/10.2307/2009925

Kompas.com. (2019a, July 18). Pemprov DKI Perpanjang Masa Penampungan Pencari Suaka, UNHCR Langsung Curhat Halaman all - Kompas.com. Retrieved from https://megapolitan.kompas.com/read/2019/07/18/08024141/pemprov-dki-

perpanjang-masa-penampungan-pencari-suaka-unhcr-langsung?page=all

Kompas.com. (2019b, August 30). DKI Bakal Kirim Nota Keberatan ke UNHCR jika Pencari Suaka Tak Pindah dari Pengungsian Kalideres. Retrieved from https://megapolitan.kompas.com/read/2019/08/30/16353021/dki-bakal-kirim-notakeberatan-ke-unhcr-jika-pencari-suaka-tak-pindah

Lecours, A. (2008). Political Issues of Paradiplomacy: Lessons from the Developed World. Clingendael Institute. Retrieved from http://www.jstor.org/stable/resrep05373

Makarychev, A. (2018). Bordering and Identity-Making in Europe After the 2015 Refugee Crisis. Geopolitics, 23(4), 747-753. https:// doi.org/10.1080/14650045.2018.1499380

Mascareñas, B. G., \& Amador, G. M. M. (2019). The Multilevel Governance of Refugee Reception policies in Spain. In Ceaseval Research On The Common European Asylum System, (18). Retrieved from http://ceaseval.eu/publications/WP3_Spain.pdf

McConnell, F., Moreau, T., \& Dittmer, J. (2012). Mimicking state diplomacy: The legitimizing strategies of unofficial diplomacies. Geoforum, 43(4), 804-814. https:// doi.org/10.1016/j.geoforum.2012.01.007

Missbach, A., Adiputera, Y., Prabandari, A., Cintika, G., Darningtyas, R., Swastika, F.Y., \& Darningtyas, R. (2018). Stalemate: Refugees in Indonesia. Presidential Regulation No. 125/2016. CILIS Policy Paper 14. Melbourne: Centre for Indonesian Law, Islam and Society, Melbourne Law School. Retrieved from https://law.unimelb.edu.au/centres/cilis/research/publications/cilis-policypapers/stalemate-refugees-in-indonesia-presidential-regulation-no-125-of-2016

Mukti, T. A., Warsito, T., Badruzaman, I., \& Pribadi, U. (2019). Paradiplomacy Management and Local Political Movement in Aceh, Indonesia, and Catalonia, Spain. European Journal of East Asian Studies, 18(1), 66-92. https://doi.org/10.1163/15700615-01801003

Palmer, W., \& Missbach, A. (2019, July 2). Over a month on in post-election Australia: No mercy for refugees in Indonesia. Retrieved from https://theconversation.com/over-a-monthon-in-post-election-australia-no-mercy-for-refugees-in-indonesia-118594

Copyright ( ) 2020. Owned by Author(s), published by Society. This is an open-access article under the CC-BY-NC-SA license. https://doi.org/10.33019/society.v8i2.218

578 
Panizzon, M., \& van Riemsdijk, M. (2018). Introduction to Special issue: 'migration governance in an era of large movements: a multi-level approach.' Journal of Ethnic and Migration Studies, 45(8), 1225-1241. https:/ / doi.org/10.1080/1369183x.2018.1441600

Paquin, S., \& LaChapelle, G. (2005). Why do sub-states and regions practice international relations. In S. Paquin, \& G. LaChapelle (Eds.), Mastering Globalization (1st ed., pp. 77-89). Abingdon, United Kingdom: Routledge.

Republik Indonesia. (1999, September 14). Undang-Undang Republik Indonesia Nomor 37 Tahun 1999 Tentang Hubungan Luar Negeri. Lembaran Negara Republik Indonesia Tahun $1999 \quad$ Nomor $156 . \quad$ Retrieved from https:/ /jdih.kemenkeu.go.id/fullText/1999/37TAHUN1999UU.htm

Republik Indonesia. (2000, October 23). Undang-Undang Republik Indonesia Nomor 24 Tahun 2000 Tentang Perjanjian Internasional. Lembaran Negara Republik Indonesia Tahun 2000 Nomor 185. Retrieved from https:/ / pih.kemlu.go.id/files/uu0242000.pdf

Republik Indonesia. (2014, September 30). Undang-Undang Republik Indonesia Nomor 23 Tahun 2014 Tentang Pemerintahan Daerah. Lembaran Negara Republik Indonesia Tahun 2014 Nomor 244. Retrieved from https:/ / pih.kemlu.go.id/files/UU0232014.pdf

Republik Indonesia. (2018, July 12). Peraturan Pemerintah Republik Indonesia Nomor 28 Tahun 2018 Tentang Kerja Sama Daerah. Lembaran Negara Republik Indonesia Tahun 2018 Nomor 97. Retrieved from https://setkab.go.id/wp-content/uploads/2018/07/PPNomor-28-Tahun-2018.pdf

Sadjad, M. S. \& Walden, M. (2019, October 2). The Nexus of Human Rights and Security in Indonesia's Approach to Refugees. Retrieved from https://rli.blogs.sas.ac.uk/2019/10/02/the-nexus-of-human-rights-and-security-inindonesias-approach-to-refugees/

Slaughter, A.-M. (1997). The Real New World Order. Foreign Affairs, 76(5), 183-197. https:/ / doi.org/10.2307/20048208

Slaughter, A.-M. (2003). Global Government Networks, Global Information Agencies, and Disaggregated Democracy. Michigan Journal of International Law, 24(4), 1041. Retrieved from https:/ / repository.law.umich.edu/mjil/vol24/iss4/7

Stalker, P. (2008). The No-Nonsense Guide to International Migration. Northamptonshire, United Kingdom: New Internationalist.

Tempo.co. (2020, July 25). Pencari Suaka di Kalideres Sulit Taat Protokol Kesehatan, Kenapa? Retrieved from https://metro.tempo.co/read/1368988/pencari-suaka-di-kalideres-sulittaat-protokol-kesehatan-kenapa

The Guardian. (2019, September 13). "It's impossible to do anything": Indonesia's refugees in limbo as money runs out. Retrieved from https:/ / www.theguardian.com/world/2019/sep/13/its-impossible-to-do-anythingindonesias-refugees-in-limbo-as-money-runs-out

Totoricagüena, G. (2005). Diasporas as Non-Central Government Actors in Foreign Policy: The Trajectory of Basque Paradiplomacy. Nationalism and Ethnic Politics, 11(2), 265-287. https:/ / doi.org/10.1080/13537110591005757

United Nations High Commissioner for Refugees. (n.d.). What We Do. Retrieved from https://www.unhcr.org/what-we-do.html

United Nations High Commissioner for Refugees. (2020a, June 18). Figures at a Glance. Retrieved from https:/ / www.unhcr.org/figures-at-a-glance.html

United Nations High Commissioner for Refugees. (2020b, July 7). Indonesia | Global Focus. Retrieved from https://reporting.unhcr.org/node/10335

Copyright ( ) 2020. Owned by Author(s), published by Society. This is an open-access article under the CC-BY-NC-SA license. https://doi.org/10.33019/society.v8i2.218 
Vigneswaran, D. (2008). Enduring territoriality: South African immigration control. Political Geography, 27(7), 783-801. https://doi.org/10.1016/j.polgeo.2008.10.003

VIVA.co.id. (2019, September 4). JK Minta Mensos Bantu Anies Cari Tempat Penampungan Pencari Suaka. Retrieved from https://www.viva.co.id/berita/metro/1232275-jk-mintamensos-bantu-anies-cari-tempat-penampungan-pencari-suaka

Willetts, P. (2001). Transnational Actors and International Organizations in Global Politics. In J. Bayliss, S. Smith, \& P. Owens (Eds.), The Globalisation of World Politics (6th ed., pp. 356383). Oxford, United Kingdom: Oxford University Press.

Wolff, S. (2007). Paradiplomacy: scope, opportunities and challenges. The Bologna Center Journal of International Affairs, 10(1), 141-150. Retrieved from https://stefanwolff.com/wpcontent/uploads/2006/07/Paradiplomacy-1.pdf

Zhang, H. X., Kelly, P. M., Locke, C., Winkels, A., \& Adger, W. N. (2006). Migration in a transitional economy: Beyond the planned and spontaneous dichotomy in Vietnam. Geoforum, 37(6), 1066-1081. https://doi.org/10.1016/j.geoforum.2006.05.009

\section{About the Authors}

1. Ignatius Hubert, a student at the Department of International Relations, Faculty of Social and Political Sciences, Universitas Padjadjaran, Indonesia.

E-Mail: ignatius17004@mail.unpad.ac.id

2. Windy Dermawan, obtained his Doctoral degree in International Relations from Universitas Padjadjaran, Indonesia, in 2018. The author is an Assistant Professor at the Department of International Relations, Faculty of Social and Political Sciences, Universitas Padjadjaran, Indonesia.

E-Mail: windy.dermawan@unpad.ac.id 